FÉCONDATION, IMPLANTATION, UTÉRUS

\title{
EFFET DU MILIEU TUBAIRE SUR LA FÉCONDATION RETARDÉE CHEZ
} LA LAPINE. - O. BOMSEL-HELMREICH, D. SZÖLLÖSI. I. N. R. A., Jouy en Josas (France).

Nous avions démontré précédemment l'effet néfaste du milieu tubaire sur la fécondation si celle-ci a lieu dans des trompes âgées entre I9 et 26 heures après le coït. Cette fécondation demeure normale si elle se produit rapidement après la transplantation d'un œuf jeune dans une trompe âgée (de o à $\mathrm{I} h$ de séjour). Mais, dès $3 \mathrm{~h}$ de séjour la fécondabilité baisse considérablement. Une période critique de vieillissement du milieu tubaire apparait $25 \mathrm{~h}$ après le coît et qui agit sur la fécondabilité. De plus, le vieillissement semble retarder la $\mathrm{I}^{\mathrm{re}}$ segmentation de l'œuf et augmente la mortalité embryonnaire aussi bien avant qu'après l'implantation.

\section{EFFET DE LA BIOVARIECTOMIE SUR LE FLUX SANGUIN UTÉRIN ET SUR LA PRESSION PA RTIELLE D'OXYGÈNE INTRA UTÉRINE CHEZ LA RATTE DU Be AU 12 JOUR DE LA GESTATION. - M. ClabAUt. Faculté des Sciences de Rouen (France).}

Chez la ratte entre le $8^{\mathrm{e}}$ et le $\mathrm{I}^{\mathrm{e}}$ jour de la gestation, la biovariectomie induit à la $24^{\mathrm{e}}$ heure une décroissance du flux sanguin utérin et une diminution de la pression partielle d'oxygène intrautérine.

Le flux sanguin a été mesuré par la technique de pléthysmographie d'impédance, les mesures de pression partielle d'oxygène intrautérine réalisées avec une microélectrode à $\mathrm{pO}_{2}$ (Beckman). Ces perturbations hémodynamiques et la diminution de la. $\mathrm{pO}_{2}$ intrautérine doivent contribuer à engendrer la mort foetale.

\section{RNA SYNTHESIS IN CELLS OF THE LUMINAL EPITHELIUM AND STROMA OF RAT UTERUS DURING EA RLY PREGNANCY. - P. J. HEALD, J. E. O'GRADY. University of Strathclyde, Glasgow (G. B.).}

We have previously shown that there is increased RNA synthesis involving the production of a new species in the rat uterus by day 5 of pregnancy, which can be correlated with the development of uterine sensitivity to decidualising stimuli. In the present study the increase in RNA synthesis in the luminal epithelial and stromal cells in the horns of unilateral ovariectomised pregnant rats has been examined. It has been shown that increased RNA synthesis occurs in the pregnant horn before $0_{4}$.oo hours on the morning of day 5 . These results will be discussed in relation to the onset of the decidual response.

\section{THE IN VIVO SYNTHESIS OF DNA AND PHOSPHOLIPIDS BY FRACTIONS} OF PREGNANT RAT UTERUS. - J. E. O'GRADY, P. J. HEALD. University of Strathclyde, Glasgow (G. B.).

In pregnancy, the timing of mitosis in uterine stromal, glandular and luminal epithelial cells is well established. We have measured the DNA synthesis associated with these mitoses by determining ${ }^{3} \mathrm{H}$ Thymidine incorporation into DNA in myometrial, stromal plus glandular and luminal epithelial fractions in pregnant unilaterally ovariectomised rats. Similarly ${ }^{3} \mathbf{H}$ Choline 
was used to determine phospholipid synthesis. DNA synthesis closely precided mitosis in these fractions and stromal synthesis was significantly different in the pregnant and pseudopregnant horns. DNA and phospholipid synthesis will be discussed in relation to the state of the stromal cells at the onset of decidualisation.

\section{GESTATION ET ÉVÉNEMENTS POST PARTUM}

\section{PURIFICATION AND LACTOGENIC ACTIVITY OF AN OVINE PLACENTAL HORMONE. - J. MARTAL, J. DJIANE, C. DELOUIS. $I$. N. R. A., Jouy en Josas (France).}

An Ovine Placental Lactogenic hormone (OPL) was isolated and purified from placentas obtained at Ioo-I20 days of pregnancy. Lactogenic activities of various fractions have been measured by a radioreceptor assay, through competitive binding with prolactin. Principal steps of purification were : homogenization of foetal cotyledons, saline extraction at $\mathrm{pH} 9.5$, acid precipitation at $\mathrm{pH} 4.5$, ammonium sulfate precipitation (65 p. roo saturation). After dialysis, the product is fractionnated on DEAE Sephadex, lyophilized and filtered on G-75 S. F. Sephadex.

This purified hormone, studied by disc gel electrophoresis, showed only one band that migrated slowly to the anode, like sheep growth hormone. According to several immunological analysis, it was neither contaminated by ovine growth hormone nor by ovine prolactin. The purified hormone retained lactogenic activity in pseudopregnant rabbit mammary gland organ cultures. Lactogenesis in vitro was estimated by histological examination, by the appearance of lactosesynthetase activities, the increase of galactosyltransferase activities and the appearance of casein synthesis.

\section{EVOLUTION IN THE SERUM OF A PLACENTAL LACTOGENiC HORMONE DURING PREgNANCY IN RUMINANTS. - J. DJIANE and G. KANN. I. N. R. A., Jouy en Josas (France).}

Co-cultures of mammary gland and sheep foetal cotylodonary tissue showed that placenta produced a lactogenic hormone. This hormone did not immunologically cross-react with ovine prolactin antibodies and bound to the same hormone receptor of the plasmic membranes prepared from lactating rabbit mammary glands. The levels of this hormone were estimated by a radioreceptor assay. In the ewe, a significant level of ovine placental lactogen (OPL) was present in serum obtained from day 80 of pregnancy; the highest level was observed about day I20; a few days before parturition OPL decreased rapidly in the serum. In the goat, lactogenic activity of the placenta was lower than in the sheep but higher than in the cow. In the cow, the lactogenic activity measured in the serum the last two months of pregnancy was very low. Ergocryptin (CB ${ }_{54}$ Sandoz) administration which inhibited prolactin release did not reduce OPL levels in the serum.

\section{Relationship between plasma esthogens levels of PRegnant COW AND SHEEP AND YOUNG BIRTH WEIGHT. - M. TERQUI, C. DELOUIS, G. KANN. I. N.R. A., 37380 Nouzilly, I. N. R. A., 78350 Jouy en Josas (France).}

Total plasma oestrogens were measured by radioimmunoassay after enzymatic hydrolysis and extraction of peripheral plasma from pregnant cows and sheep. The level of conjugated oestrogens was higher than that of free oestrogens. 